\title{
Short-Term Exposure to Fine Particulate Matter and Hospitalizations for Acute Lower Respiratory Infection in Korean Children: A Time-Series Study in Seven Metropolitan Cities
}

\author{
Jongmin Oh ${ }^{1,+}\left(\mathbb{D}\right.$, Changwoo Han ${ }^{2,+}$, Dong-Wook Lee ${ }^{3}$, Yoonyoung Jang ${ }^{3}$, Yoon-Jung Choi ${ }^{3,4} \mathbb{D}$, Hyun Joo Bae ${ }^{5}$, \\ Soontae Kim ${ }^{6}$ (D), Eunhee Ha ${ }^{1}$, Yun-Chul Hong ${ }^{3,4, *}$ and Youn-Hee Lim ${ }^{7}$ (D) \\ 1 Department of Occupational and Environmental Medicine, School of Medicine, Ewha Womans University, \\ Seoul 120-750, Korea; Jongminoh@ewha.ac.kr (J.O.); eunheeha@ewha.ac.kr (E.H.) \\ 2 Department of Preventive Medicine, Chungnam National University College of Medicine, \\ Daejeon 301-747, Korea; cwohan@cnu.ac.kr \\ 3 Department of Preventive Medicine, Seoul National University College of Medicine, Seoul 110-799, Korea; \\ is2uz@snu.ac.kr (D.-W.L.); yuyujang88@snu.ac.kr (Y.J.); hierica8@snu.ac.kr (Y.-J.C.) \\ 4 Environmental Health Center, Seoul National University College of Medicine, Seoul 03080, Korea \\ 5 Korea Environment Institute, Sejong 30147, Korea; hjbae@kei.re.kr \\ 6 Department of Environmental and Safety Engineering, Ajou University, Suwon 16499, Korea; \\ soontaekim@ajou.ac.kr \\ 7 Department of Public Health, University of Copenhagen, 1599 Copenhagen, Denmark; \\ limyounhee@gmail.com \\ * Correspondence: ychong1@snu.ac.kr; Tel.: +82-2-740-8394; Fax: +82-2-747-4830 \\ + Contribute equally as first author.
}

\section{check for}

updates

Citation: Oh, J.; Han, C.; Lee, D.-W.; Jang, Y.; Choi, Y.-J.; Bae, H.J.; Kim, S.; Ha, E.; Hong, Y.-C.; Lim, Y.-H. Short-Term Exposure to Fine Particulate Matter and Hospitalizations for Acute Lower Respiratory Infection in Korean Children: A Time-Series Study in Seven Metropolitan Cities. Int. J. Environ. Res. Public Health 2021 18, 144. https://dx.doi.org/10.3390/ ijerph18010144

Received: 30 October 2020 Accepted: 23 December 2020

Published: 28 December 2020

Publisher's Note: MDPI stays neutral with regard to jurisdictional claims in published maps and institutional affiliations.

Copyright: (c) 2020 by the authors. Licensee MDPI, Basel, Switzerland. This article is an open access article distributed under the terms and conditions of the Creative Commons Attribution (CC BY) license (https: / / creativecommons.org/ licenses/by/4.0/).
Abstract: Although several studies have evaluated the association between fine particulate matter $\left(\mathrm{PM}_{2.5}\right)$ and acute lower respiratory infection (ALRI) in children, their results were inconsistent Therefore, we aimed to evaluate the association between short-term exposure to $\mathrm{PM}_{2.5}$ and ALRI hospitalizations in children ( $0-5$ years) living in seven metropolitan cities of Korea. The ALRI hospitalization data of children living in seven metropolitan cities of Korea from 2008 to 2016 was acquired from a customized database constructed based on National Health Insurance data. The time-series data in a generalized additive model were used to evaluate the relationship between ALRI hospitalization and 7-day moving average $\mathrm{PM}_{2.5}$ exposure after adjusting for apparent temperature, day of the week, and time trends. We performed a meta-analysis using a two-stage design method. The estimates for each city were pooled to generate an average estimate of the associations. The average $\mathrm{PM}_{2.5}$ concentration in 7 metropolitan cities was $29.0 \mu \mathrm{g} / \mathrm{m}^{3}$ and a total of 713,588 ALRI hospitalizations were observed during the 9-year study period. A strong linear association was observed between $\mathrm{PM}_{2.5}$ and ALRI hospitalization. A $10 \mu \mathrm{g} / \mathrm{m}^{3}$ increase in the 7-day moving average of $\mathrm{PM}_{2.5}$ was associated with a $1.20 \%$ (95\% CI: 0.71, 1.71) increase in ALRI hospitalization. While we found similar estimates in a stratified analysis by sex, we observed stronger estimates of the association in the warm season $(1.71 \%, 95 \% \mathrm{CI}$ : $0.94,2.48)$ compared to the cold season $(0.31 \%, 95 \% \mathrm{CI}$ : $-0.51,1.13)$. In the two-pollutant models, the $\mathrm{PM}_{2.5}$ effect adjusted by $\mathrm{SO}_{2}$ was attenuated more than in the single pollutant model. Our results suggest a positive association between $\mathrm{PM}_{2.5}$ exposure and ALRI hospitalizations in Korean children, particularly in the warm season. The children need to refrain from going out on days when $\mathrm{PM}_{2.5}$ is high.

Keywords: fine particulate matter; acute lower respiratory infection; time-series; children

\section{Introduction}

Many studies have reported that fine particulate matter $\left(\mathrm{PM}_{2.5}\right)$ is associated with respiratory morbidity and the mortality of children [1-3]. Children's respiratory systems can 
be more susceptible to $\mathrm{PM}_{2.5}$ due to their fast breathing rate, narrow bronchi, and immature immune system $[4,5]$. Exposure to $\mathrm{PM}_{2.5}$ in children has been linked to respiratory diseases such as asthma, allergic inflammation, and acute lower respiratory infection (ALRI) [6-9].

ALRI is an ordinary respiratory disease in young children, and its clinical symptoms are characterized by fever, shortness of breath, sore throat, and cough. Acute bronchitis and bronchiolitis, influenza, and pneumonia are included in ALRI [10]. Globally, ALRI is the fifth major cause of child death, accounting for $30 \%$ to $50 \%$ of child hospitalizations $[7,11]$.

The Global Burden of Disease group suggested that air pollution, including $\mathrm{PM}_{2.5}$, is a risk factor for ALRI in children [7,11,12]. Respiratory infections in children or newborns can be fatal, and they also put a considerable burden on parents. Some previous studies reported evidence supporting the biological plausibility of an association between $\mathrm{PM}_{2.5}$ and ALRI. $\mathrm{PM}_{2.5}$ is comprised of diverse heavy metals and organic components and may persuade oxidative stress and inflammation in the lung tissues $[13,14]$. Toxicological research studies have shown that $\mathrm{PM}_{2.5}$ exposure may lead to impaired immune responses by altering the phagocytic activities of alveolar macrophages and reducing antioxidant levels $[7,15]$.

Previous studies showed inconsistent results regarding $\mathrm{PM}_{2.5}$ exposure and ALRI in children. Although several epidemiology studies in China, the US and Australia showed positive associations $[1,10,16]$, some studies have found no association between $\mathrm{PM}_{2.5}$ and ALRI in children $[17,18]$.

Korea has relatively high $\mathrm{PM}_{2.5}$ levels (annual mean concentration of $25 \mu \mathrm{g} / \mathrm{m}^{3}$ in 2016) among the countries of the Organization for Economic Co-operation and Development [19] and a high prevalence of pediatric ALRI hospitalization (20-30\% prevalence) [20]. However, a recent Korean study showed no relationship between $\mathrm{PM}_{2.5}$ and nationwide childhood respiratory hospitalization in 2013-2015 [21]. Given the high concentration levels of $\mathrm{PM}_{2.5}$ and the prevalence of ALRI in metropolitan cities, additional studies of any association, particularly in urban areas, are urgently needed. In some previous studies, only certain cities were considered to be within the scope of the research area $[16,18,22]$. In other cases, the study period was relatively short [21]. The inconsistency of prior research may be due to differences in exposure by region, which may result in regional differences, and the short duration of the study may also be a factor. In this study, we investigated the relationship between $\mathrm{PM}_{2.5}$ and children's ALRI hospitalization using the Korea's National Health Insurance data over a longer period (2008-2016). The aim of our study was to evaluate the impact of short-term exposure to $\mathrm{PM}_{2.5}$ on ALRI in children. We also investigated sex- and season-specific estimates.

\section{Methods}

\subsection{Number of Daily Children's ALRI Hospitalization}

In this study, we utilized the children's ALRI hospitalization data archived from the National Health Insurance Database (NHID) in South Korea. The NHID contains all of the medical information of the insured persons, including hospital visits (date of admission, date of discharge, and diagnostic codes) and personal information (sex, birth year, and residential address). Detailed information on NHID and its customizing processes for researchers have been described elsewhere [23]. Since this data is big data, it can represent the characteristics of the population. The National Health Information Service (NHIS) prepares queries and provides data at the request of researchers. We claimed information on ALRI hospitalization for children living in seven metropolitan cities (Seoul, Busan, Daegu, Incheon, Daejeon, Gwangju, and Ulsan) of South Korea from 2008 to 2016 (Figure 1). The ALRI hospitalization was determined by the International Classification of Disease, 10th revision diagnostic codes: either primary or secondary diagnostic codes of J20-J22 (J20: Acute bronchitis, J21: Acute bronchiolitis, J22: Unspecified acute lower respiratory infection). Daily counts of hospitalization for ALRI were calculated in each metropolitan city. 


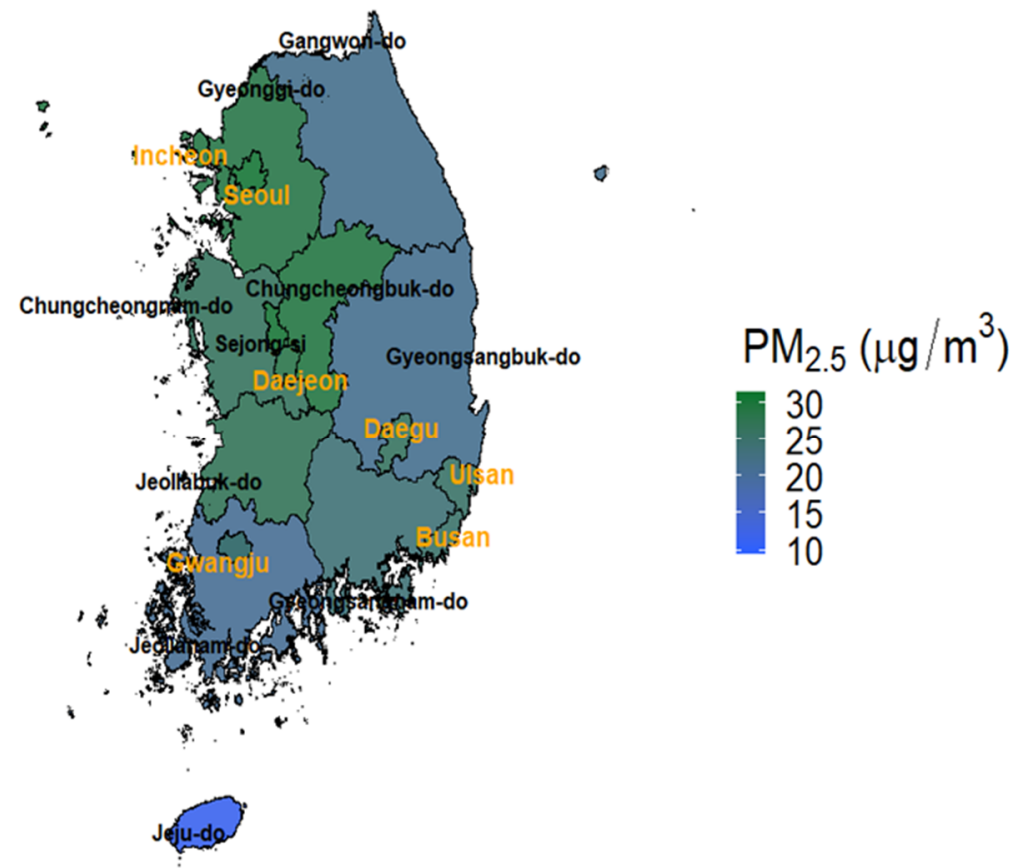

Figure 1. Map of Korea and average fine particulate matter $\left(\mathrm{PM}_{2.5}\right)$ concentrations during the study period (2008-2016). The names of seven metropolitan cities are indicated with orange color.

This study uses the unidentifiable data prepared by the NHIS and follows the guidelines for the protection of personal information provided by the NHIS. Therefore, our research was exempted from deliberation by the Institutional Review Board (E-1807-038-956) of Seoul National University Hospital.

\section{2. $P M_{2.5}$ Modeling Data}

Since the nationwide monitoring system for $\mathrm{PM}_{2.5}$ levels has only been in operation since 2015, we used the Community Multiscale Air Quality (CMAQ, version 4.7.1) modeling system to estimate $\mathrm{PM}_{2.5}$ concentrations in areas throughout the study period (2008-2016). These modeling data are designed by the US Environment Protection Agency. Several previous studies have used this modelled data [24,25]. A detailed description of the CMAQ $\mathrm{PM}_{2.5}$ data is given in Supplementary Materials Test S1. Exposure values were estimated for each of 74 administrative districts in seven cities. We calculated the modeled data by administrative districts on a daily average by city.

\subsection{Air Pollution Monitoring Data and Environmental Variables}

We also collected data on other air pollutants to construct multiple pollutant models, considering that a single pollutant can be biased or misleading [26].

Information on $\mathrm{PM}_{10}$, sulfur dioxide $\left(\mathrm{SO}_{2}\right)$, nitrogen dioxide $\left(\mathrm{NO}_{2}\right)$, carbon monoxide (CO) and ozone $\left(\mathrm{O}_{3}\right)$ was archived from the AirKorea database (https:/ / www.airkorea. or.kr/web). This database includes hourly data collected from the stationary monitoring stations located in each metropolitan area (number of monitoring stations in 2018, Seoul: 25, Busan: 17-20, Daegu: 13, Incheon: 17, Gwangju: 7, Daejeon: 10, Ulsan: 16). Measurement methods for each air pollutant are well described in previous studies. [27]. Using the hourly data of air pollutants in multiple monitoring stations, we computed daily average values for each region.

We collected the daily environmental variables (mean temperature, relative humidity, dew point temperature etc.). These data were prepared from the Korea Meteorological Administration database. We can use the data for research purposes on this website (http://www.kma.go.kr), and we have obtained the data by each city. We wanted to simplify the model by using variables containing temperature, humidity and dew point 
information. So, we used daily mean apparent temperature (AT) $[28,29]$. The equation for AT is described in the Supplementary Materials.

\subsection{Statistical Analysis}

We analyzed the time-series data for daily ALRI hospitalization count. A two-stage design was considered to investigate the relationship between $\mathrm{PM}_{2.5}$ and ALRI hospitalization. Briefly, we evaluated the generalized additive model (GAM) analysis to estimate city-specific associations. Then, we used random-effects meta-analysis to provide an effect estimate for the whole city.

In the first stage, we constructed a GAM to estimate the association between $\mathrm{PM}_{2.5}$ exposure and ALRI hospitalizations for each city. The daily ALRI hospitalization is count data and assumes a Poisson distribution in the model. Exposure-response curves in the metropolitan cities showed linear associations (Figure 2). Hereafter, we made an assumption that the association was linear between $\mathrm{PM}_{2.5}$ exposure and ALRI hospitalization. The detailed linear model is as follows:

$$
\log \left(\mu_{t}\right)=\text { Intercept }+\beta \times P M_{2.5}+s(\text { Time }, d f=7 \times 9)+s\left(A T_{t}, d f=6\right)+\gamma \times \text { Day of week }
$$

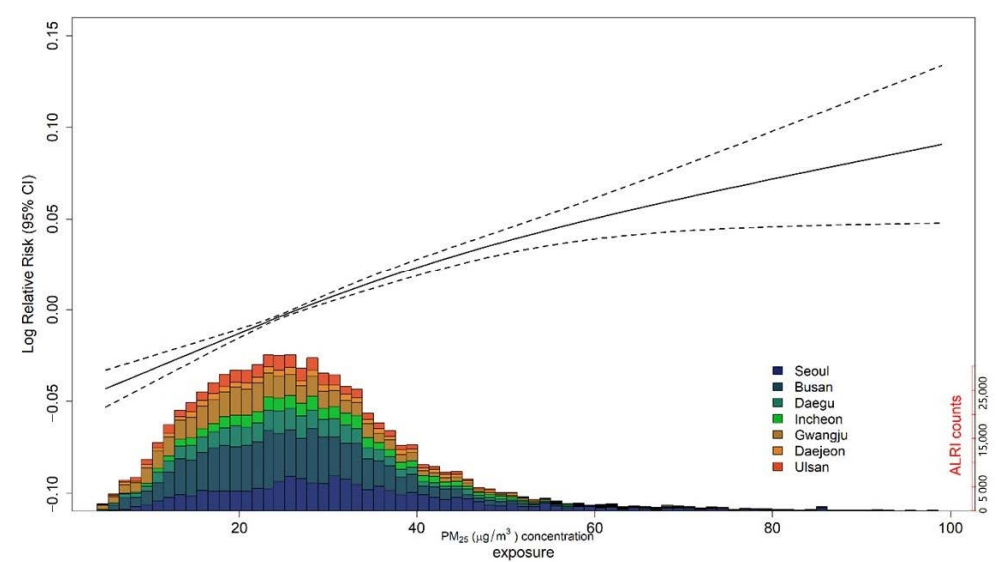

Figure 2. Exposure-response relationship between short-term $\mathrm{PM}_{2.5}$ concentrations and ALRI hospital admissions in children in seven metropolitan cities in Korea. The gray shade indicates the 95\% confidence interval. The figure below shows the ALRI hospital admission distribution over $\mathrm{PM}_{2.5}$ concentrations. All models used the 7-day moving average exposure to $\mathrm{PM}_{2.5} \mu \mathrm{g} / \mathrm{m}^{3}$. The percentage change is calculated as the change per $\mathrm{PM}_{2.5} 10 \mu \mathrm{g} / \mathrm{m}^{3}$ increase.

The $\mu_{t}$ is the daily ALRI hospitalization count in each metropolitan city on day $t$ and $\beta$ is the estimate of the association between $\mathrm{PM}_{2.5}$ and ALRI hospitalization, $A T_{t}$ is daily AT in a metropolitan city on day $t$, Day of week (DOW) indicates the categorical variable with a reference day of Sunday (from Monday to Sunday), $\gamma$ means the estimate of the DOW and $s$ is a penalized spline term. The spline function for Time was applied to control for unmeasured confounder (e.g., seasonality, trends) of daily ALRI hospitalization counts [30]. Since air pressure, wind speed and other meteorological variables did not improve the model, they were excluded from the main model. We estimated the associations of single$\operatorname{lag}(\operatorname{lag} 0,1, \ldots, 7)$ and moving average-lag $(\operatorname{Lag} 01,02, \ldots, 07)$ days of $\mathrm{PM}_{2.5}$ with ALRI hospitalization. To focus on the short-term effects of $\mathrm{PM}_{2.5}$ on ALRI hospitalization, we considered the following $\mathrm{PM}_{2.5}$ exposure windows: single-lag day exposure from current day (lag 0 ) to 7 days before hospitalization (lag 7) and moving average exposure by averaging $\mathrm{PM}_{2.5}$ levels for 2 days (current day and 1 previous day before hospitalization, lag 01 ) to 8 days (current day and 7 previous days before hospitalization, lag 07). The main results are evaluated as a percentage change (\%) of the odds ratio of daily ALRI hospitalization associated with a $10 \mu \mathrm{g} / \mathrm{m}^{3}$ increase in 7-day moving average exposure to $\mathrm{PM}_{2.5}$. The percentage change was calculated using the following formula: $\left(\mathrm{e}^{\beta * 10}-1\right) \times 100$. 
To select degrees of freedom $(d f)$ for time trends, we performed the analysis by allocating the $d f$ per year from 1 to 9 (i.e., $d f=1 \times 9, \ldots, 9 \times 9$ ) and evaluated the patterns of the effects estimates in each metropolitan city. The $d f$ for AT was selected by referring to previous papers [31].

We pooled the city-specific estimates of the associations between $\mathrm{PM}_{2.5}$ and ALRI hospitalizations in urban areas. We used the random effect model to account for the heterogeneity of the estimates across regions $[32,33]$. We evaluated the heterogeneity of the model through $\mathrm{I}^{2}, \mathrm{H}^{2}$ and Cochran's Q statistics. If the $\mathrm{I}^{2}$ statistic is less than $25 \%$, there is low heterogeneity, medium for 25 to $50 \%$, and high heterogeneity for greater than $50 \%$ [34].

When the $\mathrm{H}^{2}$ statistic is close to 1 , this indicates homogeneity [35]. The Cochran's $\mathrm{Q}$ statistic is based on a chi-square distribution, and a larger value means greater variation across studies rather than within subjects within a study [36]. We presented the metaanalysis results in a forest plot.

Subgroup analyses were conducted by sex (boys and girls) and season (warm season (April to September) and cold season (October to March)).

\subsection{Two-Pollutant Model}

We constructed a two-pollutant model to control for the effect of other pollutants on the ALRI hospitalization [37] because risk estimates can be affected by the accompanying air pollutants in the two-pollutant model [26]. We used the Variance Inflation Factor (VIF) for each pollutant pair to evaluate the multi-collinearity between the two pollutants (i.e., $\mathrm{PM}_{2.5}$ and other pollutants). If the VIF value of the other pollutant was less than 10, we included the pollutant in the two-pollutant models [38].

The software used for all data pre-processing and analysis are SAS Ver. 9.4 (SAS Institute Inc., Cary, NC, USA) and R Programming Language (Ver. 4.0.0, R Foundation for Statistical Computing, Vienna, Austria).

\section{Results}

\subsection{Main Results}

From 2008 to 2016, there were 713,588 cases of children (0-5 years) hospitalized in seven metropolitan cities of South Korea (Seoul: 147,225, Busan: 213,336, Daegu: 90,329, Incheon: 60,606, Gwangju: 112,196, Daejeon: 34,944, and Ulsan: 54,952) (Table 1). The number of daily ALRI hospitalizations was slightly higher in boys $(n=397,333(55.7 \%))$ than in girls $(n=316,255(44.3 \%))$. The daily ALRI hospitalization distribution shows the shape of a right-skewed distribution (Figure S1). Table 2 describes the summary statistics for daily air pollutants and environmental variables. The average (standard deviation, SD) daily $\mathrm{PM}_{2.5}$ concentration during the 2008 to 2016 was $29.0(7.6) \mu \mathrm{g} / \mathrm{m}^{3}$ (Gwangju being the lowest, $24.8(7.9) \mu \mathrm{g} / \mathrm{m}^{3}$ and Seoul being the highest, $30.6(8.3) \mu \mathrm{g} / \mathrm{m}^{3}$ ) (Figure 1 and Table 2). The average (SD) daily $\mathrm{SO}_{2}, \mathrm{NO}_{2}$ and $\mathrm{O}_{3}$ concentrations (ppm) were $0.005(0.002)$, $0.024(0.009)$ and $0.025(0.010)$, respectively.

Table 1. Number of acute lower respiratory infection (ALRI) hospitalizations by sex and season for the seven metropolitan cities of Korea from 2008 to 2016. The warm season is April-September and the cold season is January-March, OctoberDecember.

\begin{tabular}{ccccccccc}
\hline Category & Total & Seoul & Busan & Daegu & Incheon & Gwangju & Daejeon & Ulsan \\
\hline Sex & & & & & & & & \\
Boys & 397,333 & 19,855 & 85,099 & 116,538 & 61,456 & 34,358 & 49,815 & 30,212 \\
Girls & 316,255 & 15,059 & 62,126 & 96,798 & 50,740 & 26,248 & 40,514 & 24,740 \\
Seasons & & & & & & & & 16,566 \\
Warm & 334,766 & 66,075 & 102,548 & 41,269 & 29,095 & 52,887 & 26,326 \\
Cold & 378,822 & 81,150 & 110,788 & 49,060 & 31,511 & 59,309 & 18,378 & 28,626 \\
Total & 713,588 & 147,225 & 213,336 & 90,329 & 60,606 & 112,196 & 34,944 & 54,952 \\
\hline
\end{tabular}




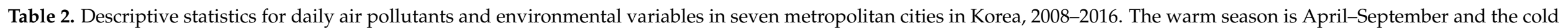
season is January-March, October-December.

\begin{tabular}{|c|c|c|c|c|c|c|c|c|c|c|}
\hline \multirow{2}{*}{ Category } & \multirow{2}{*}{ Total } & \multicolumn{2}{|c|}{ Season } & \multicolumn{7}{|c|}{ Cities } \\
\hline & & Warm & Cold & Seoul & Busan & Daegu & Incheon & Gwangju & Daejeon & Ulsan \\
\hline $\mathrm{PM}_{2.5}\left(\mu \mathrm{g} / \mathrm{m}^{3}\right)$ & $29.0(7.6)$ & $24.2(13.4)$ & 30.1 (17.2) & $30.6(8.3)$ & $25.3(6.1)$ & $26.4(6.9)$ & $29.1(8.3)$ & $24.8(7.9)$ & $28.6(9.2)$ & $25.6(6.2)$ \\
\hline $\mathrm{PM}_{10}\left(\mu \mathrm{g} / \mathrm{m}^{3}\right)$ & 46.9 (23.7) & $43.1(23.9)$ & $50.6(28.5)$ & 47.7 (29.4) & $47.3(24.0)$ & $47.0(25.7)$ & $52.6(28.9)$ & $43.0(26.7)$ & $43.1(24.8)$ & $47.4(24.9)$ \\
\hline $\mathrm{SO}_{2}(\mathrm{ppm})$ & $0.005(0.002)$ & $0.005(0.003)$ & $0.006(0.002)$ & $0.005(0.002)$ & $0.006(0.002)$ & $0.004(0.002)$ & $0.007(0.002)$ & $0.004(0.001)$ & $0.004(0.002)$ & $0.008(0.003)$ \\
\hline $\mathrm{NO}_{2}(\mathrm{ppm})$ & 0.024 (0.009) & $0.021(0.009)$ & $0.028(0.011)$ & $0.033(0.012)$ & $0.021(0.007)$ & $0.023(0.011)$ & $0.028(0.012)$ & $0.020(0.008)$ & $0.021(0.009)$ & $0.023(0.008)$ \\
\hline $\mathrm{CO}(\mathrm{ppm})$ & $0.500(0.163)$ & $0.419(0.114)$ & $0.581(0.221)$ & $0.544(0.210)$ & $0.398(0.108)$ & $0.481(0.202)$ & $0.588(0.218)$ & $0.501(0.180)$ & $0.492(0.212)$ & $0.494(0.141)$ \\
\hline $\mathrm{O}_{3}(\mathrm{ppm})$ & $0.025(0.010)$ & $0.031(0.011)$ & $0.019(0.009)$ & $0.021(0.011)$ & $0.028(0.010)$ & $0.025(0.012)$ & $0.024(0.011)$ & $0.027(0.012)$ & $0.024(0.013)$ & $0.026(0.010)$ \\
\hline Mean apparent temperature $\left({ }^{\circ} \mathrm{C}\right)$ & $13.9(11.5)$ & $22.8(7.7)$ & $4.9(6.8)$ & $12.7(11.9)$ & $15.2(10.2)$ & $14.5(11.2)$ & $12.7(12.2)$ & $14.3(11.9)$ & $13.1(12.2)$ & $14.5(10.7)$ \\
\hline Mean temperature $\left({ }^{\circ} \mathrm{C}\right)$ & $13.9(9.7)$ & $21.4(5.2)$ & $6.3(6.9)$ & $12.8(10.8)$ & $15.1(8.3)$ & $14.7(9.7)$ & $12.6(10.1)$ & $14.4(9.6)$ & $13.2(10.2)$ & $14.4(8.8)$ \\
\hline Mean relative humidity (\%) & $64.6(16.7)$ & $69.7(15.3)$ & $59.5(16.4)$ & $60.2(14.9)$ & $62.4(18.3)$ & $57.8(16.9)$ & $71.7(16.2)$ & $67.5(13.7)$ & $67.8(14.4)$ & $64.9(17.6)$ \\
\hline Mean dew point $\left({ }^{\circ} \mathrm{C}\right)$ & $6.5(11.6)$ & $14.9(7.3)$ & $-1.9(8.7)$ & $4.5(12.1)$ & $7.2(11.6)$ & $5.3(11.8)$ & $7.1(11.8)$ & $7.7(10.7)$ & $6.6(11.4)$ & $7.1(11.6)$ \\
\hline
\end{tabular}


We found slightly greater estimations of the associations when we applied 1 to $4 d f$ per year (Figure S2). Therefore, we selected $7 d f$ per year ( $63 d f=7$ per year $\times 9$ years) for Time (Figure S2). The exposure-response relationship between $\mathrm{PM}_{2.5}$ and the risk of ALRI hospitalizations are presented in Figure 2. In Figure 2, we showed a strong linear association between $\mathrm{PM}_{2.5}$ and the risk of ALRI hospitalization. Figure 3 shows the cityspecific estimates and pooled estimates between $\mathrm{PM}_{2.5}$ exposure and ALRI hospitalization risk. A 7-day moving average $\mathrm{PM}_{2.5}$ was associated with a $1.20 \%$ (95\% confidence interval (CI): 0.71, 1.71) increase in ALRI hospitalization risk.

Cities

Percent change [95\% Cl]
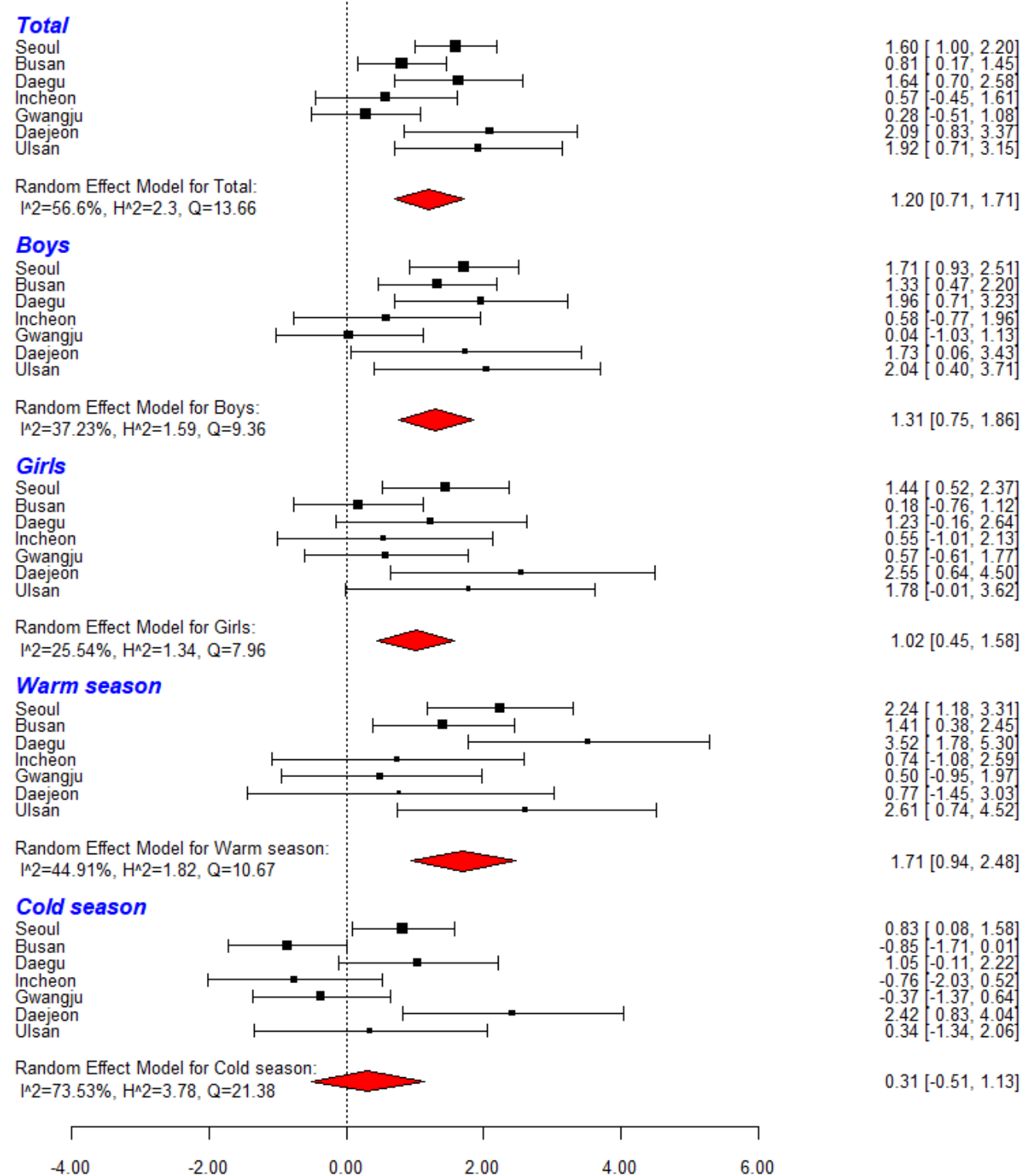

$1.20[0.71,1.71]$

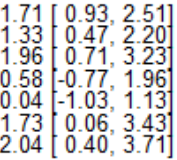

$1.31[0.75,1.86]$

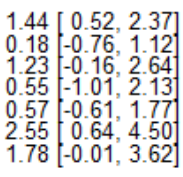

$1.02[0.45,1.58]$

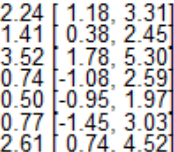

$1.71[0.94,2.48]$

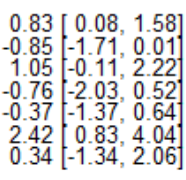

$0.31[-0.51,1.13]$

Figure 3. Meta-analysis of the association between $\mathrm{PM}_{2.5}$ and ALRI hospital admissions in seven major cities in Korea (Percentage change $(\%)$ per $10 \mu \mathrm{g} / \mathrm{m}^{3}$ ). All models were used the 7-day moving average exposure to $\mathrm{PM}_{2.5} \mathrm{\mu g} / \mathrm{m}^{3}$. Time-series model adjusted for same covariates (time, AT, day of weeks)

\subsection{Subgroup Analysis}

In the stratified analysis by sex, we found a similar association of $\mathrm{PM}_{2.5}$ exposure with ALRI hospitalization (boys: 1.31\%, 95\% CI: 0.75, 1.86; girls: 1.02\%, 95\% CI: $0.45,1.58$ ). However, we also observed differences in the associations by the season. The association in 
the warm season was shown (warm season: $1.71 \%, 95 \%$ CI: 0.94, 2.48; cold season: 0.31\%, 95\% CI: $-0.51,1.13)$.

\subsection{Two-Pollutants Model}

There were positive correlations between the modeled $\mathrm{PM}_{2.5}$ and the monitored pollutants: $\mathrm{PM}_{10}$ [correlation coefficient $\mathrm{r}=0.96$ ], $\mathrm{SO}_{2}(\mathrm{r}=0.76), \mathrm{NO}_{2}(\mathrm{r}=0.68)$, and $\mathrm{CO}$ $(\mathrm{r}=0.75)$. However, there was no correlation between modeled $\mathrm{PM}_{2.5}$ and monitored $\mathrm{O}_{3}$ $\left(\mathrm{r}=-0.03\right.$ ) (Figure 4). In the two-pollutant model, we considered $\mathrm{SO}_{2}, \mathrm{NO}_{2}$ and $\mathrm{O}_{3}$. After adjusting for $\mathrm{NO}_{2}$ and $\mathrm{O}_{3}$, the model was similar to that of the single pollutant model (Table 3). However, after it was $\mathrm{SO}_{2}$ adjusted, the association with $\mathrm{PM}_{2.5}$ was unrelated (0.69\%, 95\% CI: $-0.34,1.74)$.

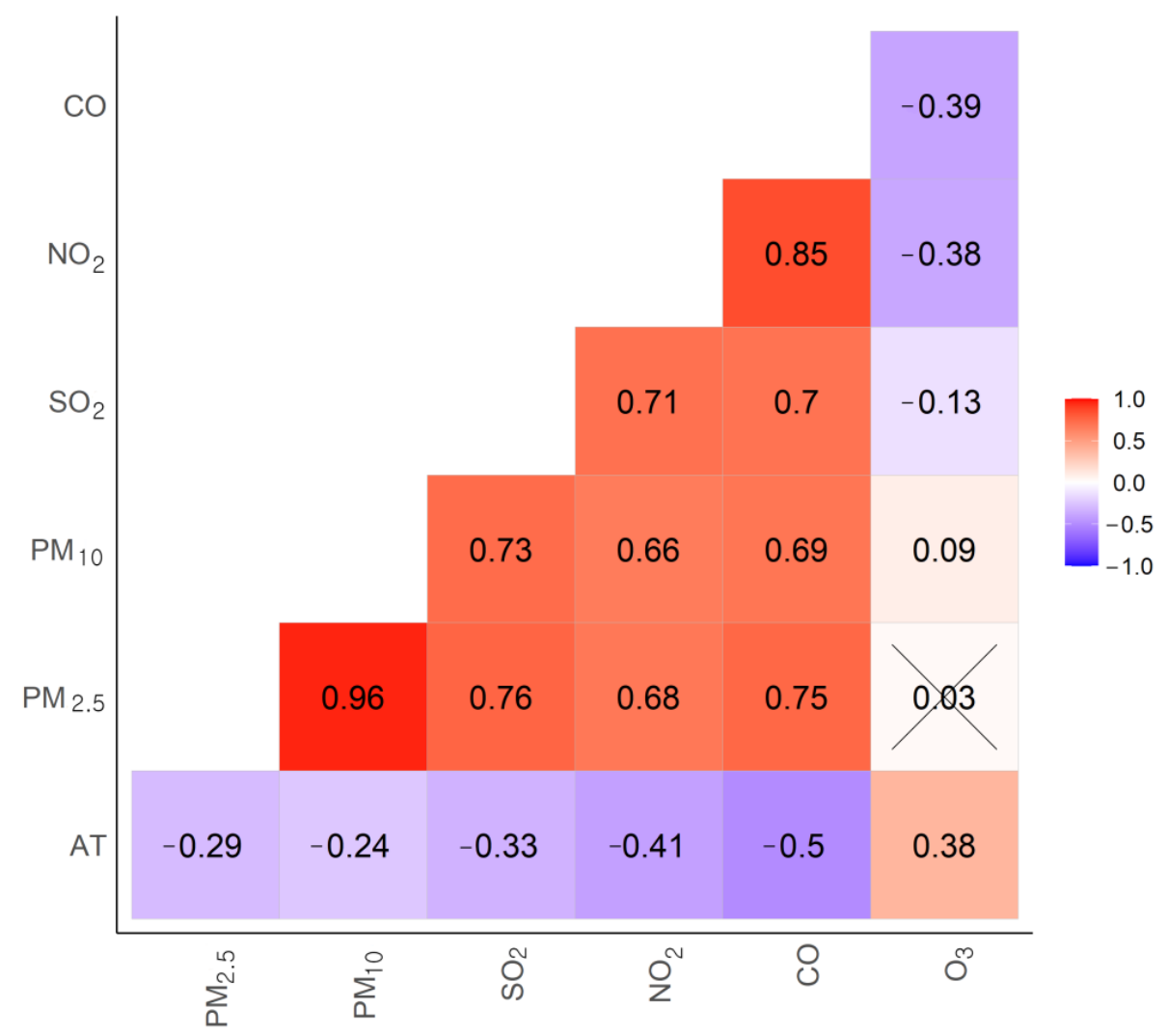

Figure 4. Spearman's correlation analysis of modeled $\mathrm{PM}_{2.5}$ and monitored air pollutants $\mathrm{PM}_{10}, \mathrm{SO}_{2}$, $\mathrm{NO}_{2}, \mathrm{CO}$, and $\mathrm{O}_{3}$ ) and apparent temperature during the study period. All correlation coefficients were statistically significant $(p$-value $<0.05)$. Statistically insignificant correlations are indicated by X-marks.

\subsection{Sensitivity Analysis}

The results for the single-day and moving average-day lag models are shown in Figure 5, Tables S1 and S2. In a single-day lag model, we observed decreasing estimates with increasing lag days (Lag 0: $0.58 \%, 95 \%$ CI: 0.41, 0.76; Lag 7: $-0.01,95 \%$ CI: -0.18 , 0.16). In the moving average lag model, the estimated association with the 7-day moving average exposure to $\mathrm{PM}_{2.5}$ was the highest (Lag 06: 1.20\%, 95\% CI: 0.71, 1.71). The residual plots and histograms for our main model in the first stage showed no specific patterns (Figure S3). In an additional analysis to validate the CMAQ Modeled $\mathrm{PM}_{2.5}$ concentration levels, we observed higher correlation coefficients between the CMAQ modeled and monitored $\mathrm{PM}_{2.5}$ data levels in each of the seven cities (0.96 or higher) (Figure S4). 
Table 3. Percentage change in $\mathrm{PM}_{2.5}$ single pollutant model and two-pollutant model. The percentage change is calculated as the change per $\mathrm{PM}_{2.5} 10 \mu \mathrm{g} / \mathrm{m}^{3}$ increase. All models used the 7-day moving average exposure to $\mathrm{PM}_{2.5} \mu \mathrm{g} / \mathrm{m}^{3}$. The time-series model was adjusted for the same covariates (time, AT, day of weeks).

\begin{tabular}{ccccc}
\hline \multirow{2}{*}{ Cities } & Single Pollutant (95\% C.I) & \multicolumn{3}{c}{ Two-Pollutant (95\% C.I) } \\
\cline { 2 - 5 } & $\mathbf{P M}_{\mathbf{2 . 5}}$ & $\mathbf{P M}_{\mathbf{2 . 5}}+\mathbf{S O}_{\mathbf{2}}$ & $\mathbf{P M}_{\mathbf{2 . 5}}+\mathbf{N O}_{\mathbf{2}}$ & $\mathbf{P M}_{\mathbf{2 . 5}}+\mathbf{O}_{\mathbf{3}}$ \\
\hline Seoul & $1.60(1.00,2.20)$ & $1.58(0.80,2.37)$ & $1.84(1.09,2.60)$ & $1.56(0.96,2.16)$ \\
Busan & $0.81(0.17,1.45)$ & $-0.96(-1.71,-0.19)$ & $0.31(-0.48,1.10)$ & $0.94(0.28,1.60)$ \\
Daegu & $1.64(0.70,2.58)$ & $1.60(0.45,2.77)$ & $1.15(0.00 .2 .32)$ & $1.55(0.60,2.50)$ \\
Incheon & $0.57(-0.45,1.61)$ & $-0.98(-2.26 .0 .32)$ & $0.62(-0.61,1.87)$ & $0.45(-0.59,1.50)$ \\
Gwangju & $0.28(-0.51,1.08)$ & $-0.09(-1.04,0.86)$ & $0.14(-0.79,1.08)$ & $-0.01(-0.84,0.83)$ \\
Daejeon & $2.09(0.83,3.37)$ & $2.70(1.09,4.34)$ & $3.01(1.55,4.49)$ & $1.74(0.44,3.05)$ \\
Ulsan & $1.92(0.71,3.15)$ & $1.45(0.00,2.92)$ & $1.40(-0.16,2.99)$ & $1.91(0.66,3.17)$ \\
Total & $1.20(0.71,1.71)$ & $0.69(-0.34,1.74)$ & $1.14(0.43,1.85)$ & $1.11(0.60,1.64)$ \\
\hline
\end{tabular}

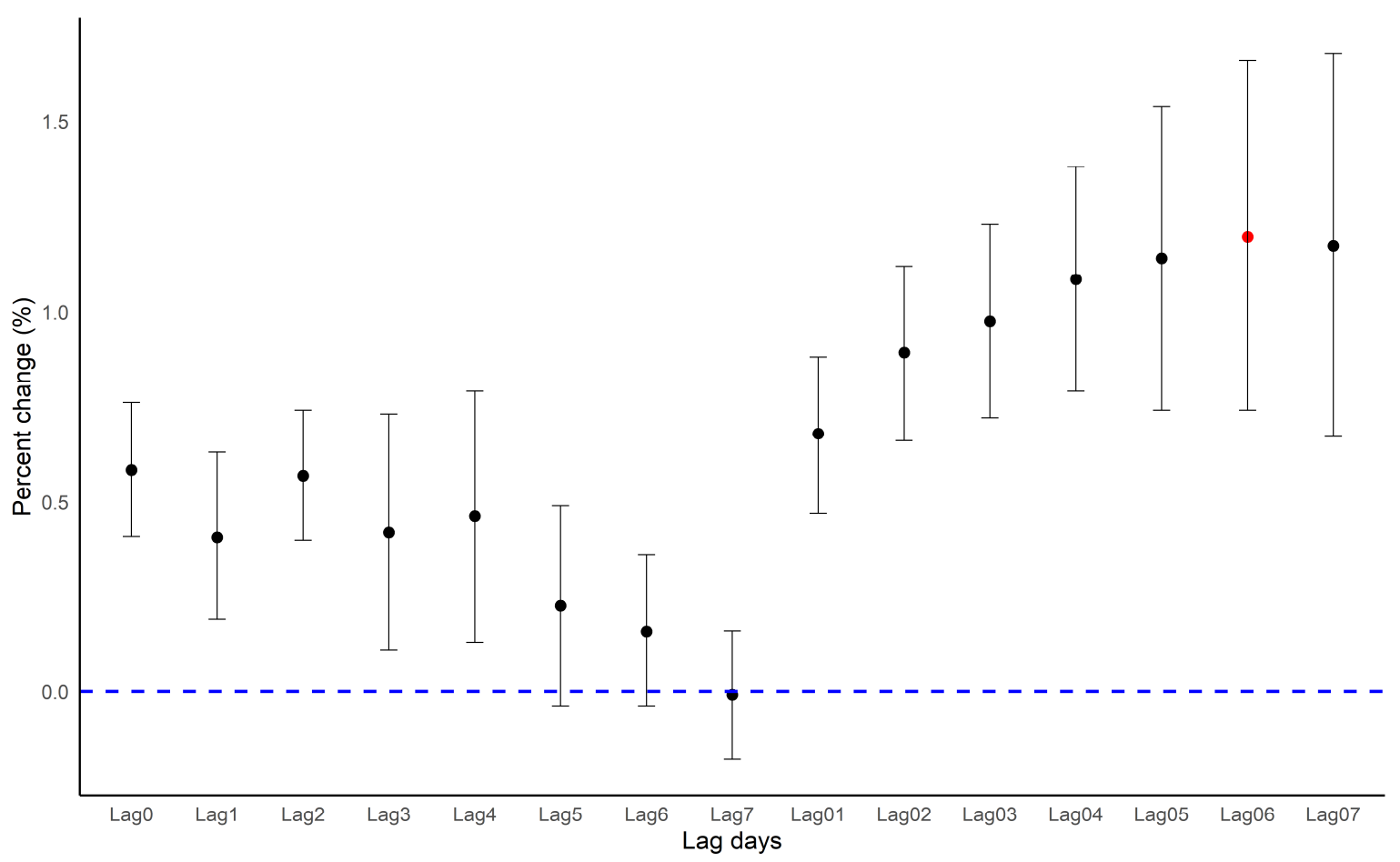

Figure 5. Percentage change (\%) for ALRI hospitalizations following single lag days (lag 0 to lag 7) and moving average (lag 01 to lag 07) $\mathrm{PM}_{2.5}$ exposure in the meta-analysis. Time-series model adjusted for the same covariates (time, AT, day of weeks). The percentage change is calculated as the change per $\mathrm{PM}_{2.5} 10 \mu \mathrm{g} / \mathrm{m}^{3}$ increase. The blue line means the border line. The red circle means the highest percentage change.

\section{Discussion}

We used the time series data for 9 years on children's ALRI hospitalization. In our study, we evaluated the association between $\mathrm{PM}_{2.5}$ and ALRI hospitalization in urban areas of South Korea. We found a $1.2 \%$ increase in ALRI hospitalization per $10 \mu \mathrm{g} / \mathrm{m}^{3}$ increase in the 7-day moving average exposure to $\mathrm{PM}_{2.5}$. A strong linear association was observed between $\mathrm{PM}_{2.5}$ and ALRI hospitalizations, and the association was stronger in the warm season. However, we found no association in the cold season. The associations of $\mathrm{PM}_{2.5}$ with ALRI hospitalization were slightly attenuated after adjusting for $\mathrm{NO}_{2}, \mathrm{O}_{3}$, and $\mathrm{SO}_{2}$ in the two-pollutant model.

Previous short-term studies have evaluated the relationship between air pollution and ALRI in children and have mostly conducted their analyses with time-series data or in a case-crossover design. Time-series data for 94,315 children under age 15 in China revealed 
the association between $\mathrm{PM}_{2.5}$ and ALRI hospitalizations ( $\leq 1: 1.26 \%(0.03,2.50 ; 2-4$ years: $1.24 \%(0.35,2.14) ; 5-14$ years old: $1.72 \%(0.34,3.12))$ [16]. In a study with time-series data from Brazil, increases of $\mathrm{PM}_{10}$ was associated with an increase in hospitalizations for pediatric or adolescent respiratory diseases, including upper respiratory tract acute infections, acute bronchitis, bronchiolitis, asthma, pneumonia, bronchopneumonia and other respiratory diseases [39]. In another case-crossover study with time-series data of 50,857 children under 3 years old in Brazil, a 4-day moving average $\mathrm{PM}_{10}$ was associated with a $4 \%$ increase in bronchiolitis hospitalizations [40]. In a case-crossover study for multi cities, exposures to $\mathrm{PM}_{2.5}, \mathrm{PM}_{10}, \mathrm{NO}_{2}$, and $\mathrm{SO}_{2}$ were associated with hospitalization of children with pneumonia and acute bronchitis [41]. In a case-crossover study with 112,467 children in the US, exposure to $\mathrm{PM}_{2.5}$ within a week was related to ALRI hospitalization aged $0-2$ years, 3-17 years and over 18 years [10]. A Malaysia study evaluated a positive association between primary air pollutants $\left(\mathrm{PM}_{10}, \mathrm{NO}_{2}\right.$ and $\left.\mathrm{O}_{3}\right)$ and ALRI hospitalization of children in cities [42].

A Vietnam study showed that exposure to $\mathrm{PM}_{2.5}$ increased ALRI hospitalization for children aged $0-4(3.51 \%, 95 \%$ CI: $0.96,6.12)$. In this time-series study, boys were higher risk of $\mathrm{PM}_{2.5}$ exposure (male: $5.22 \%, 95 \%$ CI: 0.86, 9.78; female: $-5.84,-4.30$ ) [22]. In our study, the subgroup analysis by sex was similar, but the risk for boys was slightly higher. This is probably because boys are more presumably exposed to ambient $\mathrm{PM}_{2.5}$ than girls [22]. In Korea, there was a study showing increased respiratory mortality in infants with exposure to high $\mathrm{PM}_{10}$ levels [43]. Another nationwide study in Korea in children aged 0-4 reported a stronger association between $\mathrm{PM}_{2.5}$ and ALRI hospitalization in the cold season [21]. The discrepancy between the two studies by Kim et al. and our study may come from the different definitions of ALRI hospitalization (primary diagnostic codes of ALRI in Kim et al. vs. primary or secondary diagnostic codes in our study), study periods (2013-2015 in Kim et al., vs. 2006-2015 in our study), study areas (nine provinces and seven metropolitan cities in Kim et al., vs. only seven metropolitan cities in our study), and analysis methods (a difference-in-differences approach in Kim et al., vs. a Poisson regression model in our study).

There are a few studies reporting contradictory results. A study with time-series data of US emergency room hospitalizations has revealed an association of $\mathrm{PM}_{2.5}$ with pneumonia and upper respiratory diseases, but not with bronchiolitis hospitalizations [17]. In a study with 17,118 children under 18 years old, the association between hospitalization due to pneumonia was associated with $\mathrm{PM}_{2.5}$, but bronchitis and asthma were not related to PM [44]. Another case-crossover study with 19,901 infants in California found no link between $\mathrm{PM}_{2.5}$ and bronchitis [18].

There were several previous studies considering the two-pollutants model. Zheng et al. showed that the estimate of the association with $\mathrm{PM}_{2.5}$ was not significant in the twopollutant model after controlling for $\mathrm{SO}_{2}$ and $\mathrm{NO}_{2}\left(\mathrm{PM}_{2.5}: 1.50,95 \% \mathrm{CI}: 0.35,2.66 ; \mathrm{PM}_{2.5}\right.$ adjusted for $\mathrm{SO}_{2}: 0.17,95 \% \mathrm{CI}:-2.55,0.43 ; \mathrm{PM}_{2.5}$ adjusted for $\mathrm{NO}_{2}: 0.17,95 \% \mathrm{CI}:-1.47$, 1.85) [16]. Barnett et al. argued that $\mathrm{PM}_{2.5}$ and $\mathrm{SO}_{2}$ concentration levels are a proxy measure of the same emission source (e.g., motor vehicles), and they may impact each other [41]. They showed that $\mathrm{SO}_{2}$ attenuated the effects of $\mathrm{PM}_{2.5}$ in the adjusted two-pollutant model, which is similar to our findings.

Most air pollutants, including fine dust, are caused by traffic, industries and other sources of combustion $[37,41]$. These air pollutants are highly correlated because they are affected by climatic conditions (temperature, humidity, wind speed, air pressure, and etc.). In this study, air pollutants excluding ozone were highly correlated with $\mathrm{PM}_{2.5}$ (Figure 4). Therefore, it is important to note that models containing multiple air pollutants may have collinearity.

We observed a greater estimate of the link between $\mathrm{PM}_{2.5}$ and ALRI hospitalization in the warm season. The association between $\mathrm{PM}_{2.5}$ and ALRI in children aged 1-4 was more outstanding in warm seasons in Australia and New Zealand in a previous study, which is consistent with our study [41]. A high temperature is well-known to have undesirable 
health effects; a high temperature exacerbates pre-existing health conditions [45] and is related to the death of susceptible population group (e.g., young children, elderly) [46]. Exposure to $\mathrm{PM}_{2.5}$ is associated with decreased heart rate variability (HRV), suggesting it triggers a change in the autonomic nervous system [47,48]. Interestingly, exposure to high temperature was associated with decrease in HRV during the warm season [49]. This suggests that high levels of $\mathrm{PM}_{2.5}$ and ambient temperature could have interaction effects on autonomic nervous system [50], which could interact with the immune system [51]. On the other hand, another study in San Paulo showed greater effects of $\mathrm{PM}_{10}$ during the cold season [52]; however, the average ambient temperature in San Paulo occurs during the warm season, and $13-22{ }^{\circ} \mathrm{C}$ is considered the cold season, which is very different from the significant seasonal changes in ambient temperature in Korea. Discrepancies of the season-specific associations may come from the geographical and climatic characteristics of $\mathrm{PM}_{2.5}[52,53]$. The composition of $\mathrm{PM}_{2.5}$ may vary by season, and different compositions of $\mathrm{PM}_{2.5}$ may cause various adverse effects, particularly in urban areas with heavy traffic volumes [54]. In cold seasons, while the concentration of fine dust is much higher than in warm seasons, the contributions of secondary sulfate salts and nitrate salts are greater during the summer in Beijing, China [55]. Although the $\mathrm{PM}_{2.5}$ concentration was also higher in the cold season in Seoul as well, the concentration of $\mathrm{NH}^{4+}$ was higher in the cold season while $\mathrm{SO}_{4}{ }^{2-}$ was higher during the warm season [56]. Different study periods, geographic coverages, and definitions of outcomes may also impact the study results. In addition, exposure to high temperatures and fine dust can affect the lung function of the elderly as well as in ALRI on children [57,58]. The interaction of high temperatures and $\mathrm{PM}_{2.5}$ may be the cause, and these effects need to be addressed in future studies.

Some studies have reported $\mathrm{PM}_{2.5}$ and ALRI relevance, explaining oxidative stress and inflammatory reactions as causal mechanisms. $\mathrm{PM}_{2.5}$ can cause oxidant stress to the lung tissue and induce systemic inflammation $[59,60] . \mathrm{PM}_{2.5}$ stimulates the expression of inflammatory cytokines, which may cause systematic inflammation [61].The $\mathrm{PM}_{2.5}$ inhaled in the body mainly affects macrophages and epithelial cells in the respiratory tract. In vitro and in vivo studies have described that $\mathrm{PM}_{2.5}$ reduces the phagocytic activities of alveolar macrophages, making people vulnerable to air pollutants [62,63]. Because of immature lung development, children are vulnerable to health effects if they inhale $\mathrm{PM}_{2.5}$. In addition, children breathe more air pollutants because they breathe faster than adults.

Young children may be diagnosed with ALRI for respiratory syncytial virus (RSV) infection and bronchitis. If children with RSV or bronchitis are exposed to $\mathrm{PM}_{2.5}$, the ALRI risk may increase [10].

This study has several limitations. First, we were unable to use monitored data of $\mathrm{PM}_{2.5}$ due to the short period of nationwide monitoring of $\mathrm{PM}_{2.5}$. So, we compared modeled $\mathrm{PM}_{2.5}$ levels with monitored data in 2015 and 2016 to validate the modeled concentration levels of $\mathrm{PM}_{2.5}$. We found a high correlation between modeled and monitored exposure levels in years with available data for both $\mathrm{PM}_{2.5}$ levels (2015 and 2016) (Figure S4). There are several studies that have estimated and evaluated the CMAQ PM 2.5 concentrations $[64,65]$. These studies found that CMAQ $\mathrm{PM}_{2.5}$ concentrations can be affected by weather variables (temperature, wind, etc.), emissions inventory, etc. In addition, during the 2013-2014 period, CMAQ $\mathrm{PM}_{2.5}$ concentrations may be underestimated due to high concentrations of air pollution and high emissions [64]. High concentrations were included and emissions were high in 2013 and 2014, so that the reproducibility of the simulation was somewhat lower than that of other years. However, the level of model performance evaluation was not low, so we concluded that the CMAQ $\mathrm{PM}_{2.5}$ data were suitable for our study. Second, we were unable to gather individual-level data such as socioeconomic status, parental education levels, and secondary smoking status due to the health insurance nature of the data used in our study. Third, we could not control the unmeasured confounding effects [66]. However, the time trends in the model may control for short and long-term temporal fluctuations, which may reduce unmeasured confounding effects [67]. Fourth, exposure data were applied as the daily average in each 
region. Therefore, potential misclassification may have been caused by exposure values. Finally, this research was evaluated in metropolitan cities of South Korea. Thus, our results cannot be generalized to rural areas or other countries with different $\mathrm{PM}_{2.5}$ levels.

\section{Conclusions}

Our results have revealed a link between $\mathrm{PM}_{2.5}$ and ALRI hospitalization among Korean children. The increase in $\mathrm{PM}_{2.5}$ is related to the increased ALRI hospitalization for Korean children. In particular, exposure to $\mathrm{PM}_{2.5}$ in warm seasons was highly related to ALRI. Children need to refrain from outdoor activity when $\mathrm{PM}_{2.5}$ is high. The results of our research can be used for children's health care and health policies for children's respiratory disease. Future research needs to investigate the link between air pollution, temperature and children's respiratory health.

Since $\mathrm{PM}_{2.5}$ is mainly caused by traffic and industrial emissions, government control is necessary. The South Korean government announced its 2nd Seoul Metropolitan Air Quality Control Master Plan from 2015 to 2024. It includes regulations such as reducing eco-friendly cars and carbon emissions and strengthening management around life. In the future, managing air pollution is expected to reduce children's health effects caused by exposure to air pollution.

Supplementary Materials: The following are available online at https://www.mdpi.com/1660-4 601/18/1/144/s1, Figure S1: The histogram of daily ALRI hospitalization in seven cities, in Korea, Figure S2: Estimation of log relative risk according to the degrees of freedom for time per year. The model was adjusted for apparent temperature, day of weeks and time trends, Figure S3: Residuals plots for fitted models for each region (left), and residual histograms for fitted models for each region (right), Figure S4: Correlation between daily CMAQ $\mathrm{PM}_{2.5}$ concentration and Monitoring $\mathrm{PM}_{2.5}$ concentration by region (2015-2016). Table S1: The association between single lag $\mathrm{PM}_{2.5}$ concentrations and ALRI hospital admissions among children the seven major cities in Korea, 2018-2016, Table S2: The association between moving average $\mathrm{PM}_{2.5}$ concentrations and ALRI hospital admissions among children the seven major cities in Korea, 2018-2016. The moving average is the average from the current day to the previous day. Time-series model adjusted for same covariates (time, AT, day of weeks). The percentage change is calculated as the change per $\mathrm{PM}_{2.5}$ $10 \mu \mathrm{g} / \mathrm{m}^{3}$ increase.

Author Contributions: Conceptualization: J.O., C.H., Y.-C.H. and Y.-H.L.; Methodology: J.O., C.H., D.-W.L., H.J.B., E.H., Y.-C.H. and Y.-H.L.; Formal analysis/Visualization: J.O. and C.H.; Investigation: J.O., C.H., Y.J., Y.-J.C. and S.K.; Data curation: J.O., C.H., S.K.; Writing-original draft: All authors; Writing — review and editing: J.O., C.H., D.-W.L., Y.J., Y.-J.C., Y.-C.H. and Y.-H.L. All authors have read and agreed to the published version of the manuscript.

Funding: This research was supported by the National Strategic Project-Fine Particle of the National Research Foundation of Korea, funded by the Ministry of Science, Information, Communications, and Technology, the Ministry of Environment, and the Ministry of Health and Welfare (grant nos. 2017M3D8A1092008, 2017M3D8A1092009), research fund of Chungnam National University, as well as the Center for Environmental Health through the Ministry of Environment.

Institutional Review Board Statement: The study was approved by the Institutional Review Board (IRB) of Seoul National University (E-1807-038-956).

Informed Consent Statement: This data was used de-identified data provided by National Health Insurance Service (NHIS) and complied with the NHIS personal information protection guideline. Therefore, the requirement for informed consent was waived by the IRB.

Data Availability Statement: The data used in this study is available from the NHIS. However, this data requires deliberation by the NHIS and analysis is conducted in a limited closed network. Only limited analysis results can be obtained.

Acknowledgments: This study was conducted using data from the National Health Insurance Service of Korea (NHIS-2019-1-023).

Conflicts of Interest: The authors declare they have no actual or potential competing financial interests. 


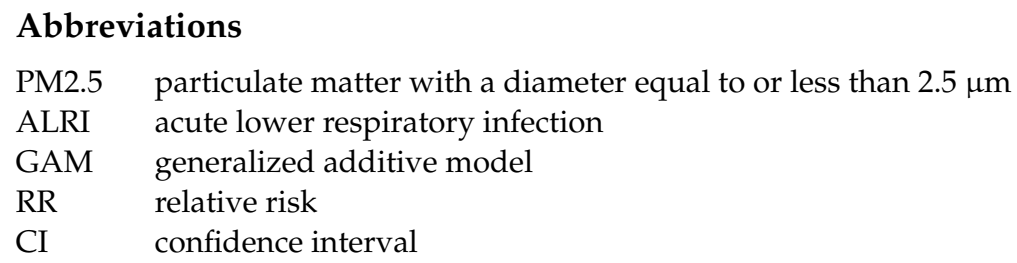

\section{References}

1. Apte, J.S.; Marshall, J.D.; Cohen, A.J.; Brauer, M. Addressing Global Mortality from Ambient PM2.5. Environ. Sci. Technol. 2015, 49, 8057-8066. [CrossRef] [PubMed]

2. Ostro, B.; Roth, L.; Malig, B.; Marty, M. The effects of fine particle components on respiratory hospital admissions in children. Environ. Health Perspect. 2009, 117, 475-480. [CrossRef] [PubMed]

3. Koenig, J.Q.; Larson, T.V.; Hanley, Q.S.; Rebolledo, V.; Dumler, K.; Checkoway, H.; Wang, S.Z.; Lin, D.; Pierson, W.E. Pulmonary function changes in children associated with fine particulate matter. Environ. Res. 1993, 63, 26-38. [CrossRef] [PubMed]

4. Grigg, J. Particulate matter exposure in children: Relevance to chronic obstructive pulmonary disease. Proc. Am. Thorac. Soc. 2009, 6, 564-569. [CrossRef] [PubMed]

5. Tecer, L.H.; Alagha, O.; Karaca, F.; Tuncel, G.; Eldes, N. Particulate matter (PM(2.5), PM(10-2.5), and PM(10)) and children's hospital admissions for asthma and respiratory diseases: A bidirectional case-crossover study. J. Toxicol. Environ. Health A 2008, 71, 512-520. [CrossRef]

6. Guarnieri, M.; Balmes, J.R. Outdoor air pollution and asthma. Lancet 2014, 383, 1581-1592. [CrossRef]

7. Mehta, S.; Shin, H.; Burnett, R.; North, T.; Cohen, A.J. Ambient particulate air pollution and acute lower respiratory infections: A systematic review and implications for estimating the global burden of disease. Air Qual. Atmos. Health 2013, 6, 69-83. [CrossRef]

8. Colley, J.R.; Douglas, J.W.; Reid, D.D. Respiratory disease in young adults: Influence of early childhood lower respiratory tract illness, social class, air pollution, and smoking. Br. Med. J. 1973, 3, 195-198. [CrossRef]

9. Spears, D.; Dey, S.; Chowdhury, S.; Scovronick, N.; Vyas, S.; Apte, J. The association of early-life exposure to ambient PM2.5 and later-childhood height-for-age in India: An observational study. Environ. Health 2019, 18, 62. [CrossRef]

10. Horne, B.D.; Joy, E.A.; Hofmann, M.G.; Gesteland, P.H.; Cannon, J.B.; Lefler, J.S.; Blagev, D.P.; Korgenski, E.K.; Torosyan, N.; Hansen, G.I.; et al. Short-Term Elevation of Fine Particulate Matter Air Pollution and Acute Lower Respiratory Infection. Am. J. Respir. Crit. Care Med. 2018, 198, 759-766. [CrossRef]

11. GBD. Estimates of the global, regional, and national morbidity, mortality, and aetiologies of lower respiratory tract infections in 195 countries: A systematic analysis for the Global Burden of Disease Study 2015. Lancet Infect. Dis. 2015, 17, 1133-1161. [CrossRef]

12. Bruce, N. Indoor air pollution from unprocessed solid fuel use and pneumonia risk in children aged under five years: A systematic review and meta-analysis. Bull. World Health Organ. 2008, 86, 390-398. [CrossRef] [PubMed]

13. Rahman, I.; MacNee, W. Role of oxidants/antioxidants in smoking-induced lung diseases. Free Radic. Biol. Med. 1996, $21,669-681$. [CrossRef]

14. Greenwell, L.L.; Moreno, T.; Jones, T.P.; Richards, R.J. Particle-induced oxidative damage is ameliorated by pulmonary antioxidants. Free Radic. Biol. Med. 2002, 32, 898-905. [CrossRef]

15. Donaldson, K.; Beswick, P.H.; Gilmour, P.S. Free radical activity associated with the surface of particles: A unifying factor in determining biological activity? Toxicol. Lett. 1996, 88, 293-298. [CrossRef]

16. Zheng, P.W.; Wang, J.B.; Zhang, Z.Y.; Shen, P.; Chai, P.F.; Li, D.; Jin, M.J.; Tang, M.L.; Lu, H.C.; Lin, H.B.; et al. Air pollution and hospital visits for acute upper and lower respiratory infections among children in Ningbo, China: A time-series analysis. Environ. Sci. Pollut. Res. Int. 2017, 24, 18860-18869. [CrossRef]

17. Darrow, L.A.; Klein, M.; Flanders, W.D.; Mulholland, J.A.; Tolbert, P.E.; Strickland, M.J. Air pollution and acute respiratory infections among children 0-4 years of age: An 18-year time-series study. Am. J. Epidemiol. 2014, 180, 968-977. [CrossRef]

18. Karr, C.; Lumley, T.; Shepherd, K.; Davis, R.; Larson, T.; Ritz, B.; Kaufman, J. A case-crossover study of wintertime ambient air pollution and infant bronchiolitis. Environ. Health Perspect. 2006, 114, 277-281. [CrossRef]

19. Health Effects Institute. State of Global Air 2017: A Special Report on Global Exposure to Air Pollution and Its Disease Burden; Health Effect Institute: Boston, MA, USA, 2017.

20. Park, J.-E.; Lee, S.-Y.; Kang, J.H. Common Disease Codes in Pediatric Inpatients (1997-2008). Korean J. Pediatric Infect. Dis. 2011, 18. [CrossRef]

21. Kim, K.N.; Kim, S.; Lim, Y.H.; Song, I.G.; Hong, Y.C. Effects of short-term fine particulate matter exposure on acute respiratory infection in children. Int. J. Hyg. Environ. Health 2020, 229, 113571. [CrossRef]

22. Luong, L.T.M.; Dang, T.N.; Thanh Huong, N.T.; Phung, D.; Tran, L.K.; Van Dung, D.; Thai, P.K. Particulate air pollution in Ho Chi Minh city and risk of hospital admission for acute lower respiratory infection (ALRI) among young children. Environ. Pollut. 2020, 257. [CrossRef] [PubMed] 
23. Seong, S.C.; Kim, Y.Y.; Khang, Y.H.; Heon Park, J.; Kang, H.J.; Lee, H.; Do, C.H.; Song, J.S.; Hyon Bang, J.; Ha, S.; et al. Data Resource Profile: The National Health Information Database of the National Health Insurance Service in South Korea. Int. J. Epidemiol. 2017, 46, 799-800. [CrossRef]

24. Oh, J.; Lee, S.; Kim, M.H.; Kwag, Y.; Kim, H.S.; Kim, S.; Ye, S.; Ha, E. The impact of PM2.5 on acute otitis media in children (aged 0-3): A time series study. Environ. Int. 2020, 145, 106133. [CrossRef] [PubMed]

25. Han, C.; Kim, S.; Lim, Y.H.; Bae, H.J.; Hong, Y.C. Spatial and Temporal Trends of Number of Deaths Attributable to Ambient PM2.5 in the Korea. J. Korean Med Sci. 2018, 33, e193. [CrossRef]

26. Tolbert, P.E.; Klein, M.; Peel, J.L.; Sarnat, S.E.; Sarnat, J.A. Multipollutant modeling issues in a study of ambient air quality and emergency department visits in Atlanta. J. Expo. Sci. Environ. Epidemiol. 2007, 17, S29-S35. [CrossRef]

27. Seo, J.; Kim, J.Y.; Youn, D.; Lee, J.Y.; Kim, H.; Lim, Y.B.; Kim, Y.; Jin, H.C. On the multiday haze in the Asian continental outflow: The important role of synoptic conditions combined with regional and local sources. Atmos. Chem. Phys. 2017, 17, 9311-9332. [CrossRef]

28. Zanobetti, A.; Schwartz, J. Temperature and Mortality in Nine US Cities. Epidemiology 2008, 19, 563-570. [CrossRef]

29. Nguyen, J.L.; Schwartz, J.; Dockery, D.W. The relationship between indoor and outdoor temperature, apparent temperature, relative humidity, and absolute humidity. Indoor Air 2014, 24, 103-112. [CrossRef]

30. Bhaskaran, K.; Gasparrini, A.; Hajat, S.; Smeeth, L.; Armstrong, B. Time series regression studies in environmental epidemiology. Int. J. Epidemiol. 2013, 42, 1187-1195. [CrossRef]

31. Alessandrini, E.; Sajani, S.Z.; Scotto, F.; Miglio, R.; Marchesi, S.; Lauriola, P. Emergency ambulance dispatches and apparent temperature: A time series analysis in Emilia-Romagna, Italy. Environ. Res. 2011, 111, 1192-1200. [CrossRef]

32. Rucker, G.; Schwarzer, G.; Carpenter, J.R.; Schumacher, M. Undue reliance on I(2) in assessing heterogeneity may mislead. BMC Med. Res. Methodol. 2008, 8, 79. [CrossRef] [PubMed]

33. Borenstein, M.; Hedges, L.V.; Higgins, J.P.; Rothstein, H.R. A basic introduction to fixed-effect and random-effects models for meta-analysis. Res. Synth. Methods 2010, 1, 97-111. [CrossRef] [PubMed]

34. Melsen, W.G.; Bootsma, M.C.; Rovers, M.M.; Bonten, M.J. The effects of clinical and statistical heterogeneity on the predictive values of results from meta-analyses. Clin. Microbiol. Infect. 2014, 20, 123-129. [CrossRef] [PubMed]

35. Dwivedi, S.N. Which is the Preferred Measure of Heterogeneity in Meta-Analysis and Why? A Revisit. Biostat. Biom. Open Access J. 2017, 1. [CrossRef]

36. Kulinskaya, E.; Dollinger, M.B. An accurate test for homogeneity of odds ratios based on Cochran's Q-statistic. BMC Med. Res. Methodol. 2015, 15, 49. [CrossRef]

37. Ito, K.; Thurston, G.D.; Silverman, R.A. Characterization of PM2.5, gaseous pollutants, and meteorological interactions in the context of time-series health effects models. J. Expo. Sci. Environ. Epidemiol. 2007, 17, S45-S60. [CrossRef]

38. Vatcheva, K.P.; Lee, M.; McCormick, J.B.; Rahbar, M.H. Multicollinearity in Regression Analyses Conducted in Epidemiologic Studies. Epidemiology (Sunnyvale) 2016, 6. [CrossRef]

39. Braga, A.L.; Saldiva, P.H.; Pereira, L.A.; Menezes, J.J.; Conceicao, G.M.; Lin, C.A.; Zanobetti, A.; Schwartz, J.; Dockery, D.W. Health effects of air pollution exposure on children and adolescents in Sao Paulo, Brazil. Pediatr. Pulmonol. 2001, 31, 106-113. [CrossRef]

40. Segala, C.; Poizeau, D.; Mesbah, M.; Willems, S.; Maidenberg, M. Winter air pollution and infant bronchiolitis in Paris. Environ. Res. 2008, 106, 96-100. [CrossRef]

41. Barnett, A.G.; Williams, G.M.; Schwartz, J.; Neller, A.H.; Best, T.L.; Petroeschevsky, A.L.; Simpson, R.W. Air pollution and child respiratory health: A case-crossover study in Australia and New Zealand. Am. J. Respir. Crit. Care Med. 2005, 171, 1272-1278. [CrossRef]

42. Ismail, S.N.S.; Abdul Rahman, S.R.; Sahani, M.; Firuz, R.; Latif, M.T. A case crossover analysis of primary air pollutants association on acute respiratory infection (ARI) among children in urban region of Klang valley, Malaysia. Ann. Trop. Med. Public Health 2017, 10. [CrossRef]

43. Ha, E.H.; Lee, J.T.; Kim, H.; Hong, Y.C.; Lee, B.E.; Park, H.S.; Christiani, D.C. Infant Susceptibility of Mortality to Air Pollution in Seoul, South Korea. Pediatrics 2003, 111, 284-290. [CrossRef] [PubMed]

44. Nhung, N.T.T.; Schindler, C.; Dien, T.M.; Probst-Hensch, N.; Perez, L.; Kunzli, N. Acute effects of ambient air pollution on lower respiratory infections in Hanoi children: An eight-year time series study. Environ. Int. 2018, 110, 139-148. [CrossRef] [PubMed]

45. Gordon, C.J. Role of environmental stress in the physiological response to chemical toxicants. Environ. Res. 2003, 92, 1-7. [CrossRef]

46. Kalkstein, L.S.; Greene, J.S. An evaluation of climate/mortality relationships in large U.S. cities and the possible impacts of a climate change. Environ. Health Perspect. 1997, 105, 84-93. [CrossRef]

47. Gold, D.R.; Litonjua, A.; Schwartz, J.; Lovett, E.; Larson, A.; Nearing, B.; Allen, G.; Verrier, M.; Cherry, R.; Verrier, R. Ambient Pollution and Heart Rate Variability. Circulation 2000, 101, 1267-1273. [CrossRef]

48. Creason, J.; Neas, L.; Walsh, D.; Williams, R.O.N.; Sheldon, L.; Liao, D.; Shy, C. Particulate matter and heart rate variability among elderly retirees: The Baltimore 1998 PM study. J. Expo. Sci. Environ. Epidemiol. 2001, 11, 116-122. [CrossRef]

49. Ren, C.; O’Neill, M.S.; Park, S.K.; Sparrow, D.; Vokonas, P.; Schwartz, J. Ambient Temperature, Air Pollution, and Heart Rate Variability in an Aging Population. Am. J. Epidemiol. 2011, 173, 1013-1021. [CrossRef] 
50. Ren, C.; Tong, S. Temperature modifies the health effects of particulate matter in Brisbane, Australia. Int. J. Biometeorol. 2006, 51, 87-96. [CrossRef]

51. Kenney, M.J.; Ganta, C.K. Autonomic Nervous System and Immune System Interactions. Compr Physiol 2014, 4, 1177-1200.

52. Gouveia, N.; Fletcher, T. Time series analysis of air pollution and mortality: Effects by cause, age and socioeconomic status. J. Epidemiol. Community Health 2000, 54, 750-755. [CrossRef] [PubMed]

53. Cox, L.A.T.; Liu, X.; Shi, L.; Zu, K.; Goodman, J. Applying Nonparametric Methods to Analyses of Short-Term Fine Particulate Matter Exposure and Hospital Admissions for Cardiovascular Diseases among Older Adults. Int. J. Environ. Res. Public Health 2017, 14, 1051. [CrossRef] [PubMed]

54. Cesari, D.; De Benedetto, G.E.; Bonasoni, P.; Busetto, M.; Dinoi, A.; Merico, E.; Chirizzi, D.; Cristofanelli, P.; Donateo, A.; Grasso, F.M.; et al. Seasonal variability of PM2.5 and PM10 composition and sources in an urban background site in Southern Italy. Sci. Total Environ. 2018, 612, 202-213. [CrossRef] [PubMed]

55. Chen, R.; Cheng, J.; Lv, J.; Wu, L.; Wu, J. Comparison of chemical compositions in air particulate matter during summer and winter in Beijing, China. Environ. Geochem. Health 2016, 39, 913-921. [CrossRef] [PubMed]

56. Park, J.; Park, E.H.; Schauer, J.J.; Yi, S.-M.; Heo, J. Reactive oxygen species (ROS) activity of ambient fine particles (PM2.5) measured in Seoul, Korea. Environ. Int. 2018, 117, 276-283. [CrossRef] [PubMed]

57. Li, J.; Woodward, A.; Hou, X.Y.; Zhu, T.; Zhang, J.L.; Brown, H.; Yang, J.; Qin, R.N.; Gao, J.H.; Gu, S.H.; et al. Modification of the effects of air pollutants on mortality by temperature: A systematic review and meta-analysis. Sci. Total Environ. 2017, 575, 1556-1570. [CrossRef] [PubMed]

58. Lepeule, J.; Litonjua, A.A.; Gasparrinie, A.; Koutrakis, P.; Sparrows, D.; Vokonas, P.S.; Schwartz, J. Lung function association with outdoor temperature and relative humidity and its interaction with air pollution in the elderly. Environ. Res. 2018, 165, 110-117. [CrossRef]

59. Zhu, L.; Ge, X.; Chen, Y.; Zeng, X.; Pan, W.; Zhang, X.; Ben, S.; Yuan, Q.; Xin, J.; Shao, W.; et al. Short-term effects of ambient air pollution and childhood lower respiratory diseases. Sci. Rep. 2017, 7, 4414. [CrossRef]

60. Lodovici, M.; Bigagli, E. Oxidative Stress and Air Pollution Exposure. J. Toxicol. 2011, 2011, 1-9. [CrossRef]

61. Sigaud, S.; Goldsmith, C.A.; Zhou, H.; Yang, Z.; Fedulov, A.; Imrich, A.; Kobzik, L. Air pollution particles diminish bacterial clearance in the primed lungs of mice. Toxicol. Appl. Pharmacol. 2007, 223, 1-9. [CrossRef]

62. Miyata, R.; van Eeden, S.F. The innate and adaptive immune response induced by alveolar macrophages exposed to ambient particulate matter. Toxicol. Appl. Pharmacol. 2011, 257, 209-226. [CrossRef] [PubMed]

63. Jalava, P.I.; Salonen, R.O.; Pennanen, A.S.; Sillanpaa, M.; Halinen, A.I.; Happo, M.S.; Hillamo, R.; Brunekreef, B.; Katsouyanni, K.; Sunyer, J.; et al. Heterogeneities in inflammatory and cytotoxic responses of RAW 264.7 macrophage cell line to urban air coarse, fine, and ultrafine particles from six European sampling campaigns. Inhal. Toxicol. 2007, 19, 213-225. [CrossRef] [PubMed]

64. Bae, M.; Kim, B.-U.; Kim, H.C.; Kim, S. A Multiscale Tiered Approach to Quantify Contributions: A Case Study of PM2.5 in South Korea during 2010-2017. Atmosphere 2020, 11, 141. [CrossRef]

65. Kim, J.-H.; Choi, D.-R.; Koo, Y.-S.; Lee, J.-B.; Park, H.-J. Analysis of Domestic and Foreign Contributions using DDM in CMAQ during Particulate Matter Episode Period of February 2014 in Seoul. J. Korean Soc. Atmos. Environ. 2016, 32, 82-99. [CrossRef]

66. VanderWeele, T.J.; Arah, O.A. Bias Formulas for Sensitivity Analysis of Unmeasured Confounding for General Outcomes, Treatments, and Confounders. Epidemiology 2011, 22, 42-52. [CrossRef]

67. Peng, R.D.; Dominici, F. Statistical Methods for Environmental Epidemiology with R: A Case Study in Air Pollution and Health; Springer: Berlin/Heidelberg, Germany, 2008. 